\title{
PELAYANAN KESEHATAN KONVENSIONAL DAN KOMPLEMENTER TERPADU BAGI WARGA BINAAN LANJUT USIA DI WILAYAH KARANG GAYAM TERATAISURABAYA
}

\author{
Mangestuti Agil*, Tutik Sri Wahyuni, Rakhmawati, Herra Studiawan \\ Departemen Farmakognosi Fitokimia, Fakultas Farmasi, Universitas Airlangga, Surabaya, Indonesia \\ *Penulis korespondensi: mangestuti@ff.unair.ac.id
}

\begin{abstract}
Abstrak
Pelay anan kesehatan konvensional dan komplementer terpadu dilaksanakan bagi wa rga binaan lanjut usia di Wilayah Karang Gayam Teratai, Surabaya dengan memberikan konsultasi kesehatan konvensional dan komplementer dengan ramuan herbal, akupunktur dan pijat. Tujuan program pengabdian masyarakat ini adalah peningkatan wa wasan tentang pengaplikasian sistem pengobatan konvensional berpadu dengan pengobatan komplementer. Titik berat pengobatan konven sional berupa kepatuhan menjalankan perintah dan nasehat dokter Pusat Kesehatan Masyarakat setempat, yaitu kepatuhan minum obat dokter, pengaturan pola hidup terutama pola makan, olahraga dan istirahat. Perpa duan dengan pengobatan komplementer berupa pemanfaatan tanaman obat, a kupunktur dan pijat yang sesuai dan menunjang pengobatan dokter. Jumlah pasien 30 orang yang semuanya mengalami gangguan penyakit kronik, y aitu dia betes mellitus, tekanan darah tinggi, kadar asam urat tinggi, kadar kolesterol darah tinggi. Berda sarkan data menunjukkan tidak terdapat satu pasien pun yang mengalami perubahan ga ngguan kesehatan pada ke empat indikator darah secara keseluruhan yang diukur. Melalui program ini dapat disimpulkan, bahwa pola hidup tidak sehat menjadi penyebab utama masalah kesehatan. Warga membutuhkan perhatian dalam bentuk konsultasi, dimana mereka dapat berdiskusi secara aktif, dan bukan tindakan pemeriksaan kesehatan dan pemberian obat saja. Pelayanan terpadu sistem konvensional dan komplementer perlu dipertimbangkan sebagai cara untuk meningkatkan kesehatan masyarakat.
\end{abstract}

Kata kunci: Pela yanan Terpadu; Komplementer; Herbal; Akupunktur; Pijat.

\begin{abstract}
Integrated conventional and complementary health care services have been conducted among elderly residents of Karang Gayam Teratai Regency in Surabaya which provided patients with necessary information on conventional combined with herbal medicine, acupuncture, massage. The aim of the program was to enhance the understanding of people in the community about the application of complementary medicine along with conventional medicine. Conventional medicine alone, or in combination has to be thoroughly taken through understanding about all necessary instructions, and conduct healthylife style. 30 patients participated in the program, where all of them contracted various kinds of chronic diseases, including high blood pressure, high blood sugar, cholesterol, uric acid levels. It is concluded from the program, that unhealthy life style is the main cause of their health problems. People showed great appreciation to every effort in giving them special time for active discussion and attention. Effective doctor-patient communication is a central clinical function in building a therapeutic doctor-patient relationship, which is the heart and art of medicine. This is important in the delivery of high-quality health care. Much patient dissatisfaction and many complaints are due to breakdown in the doctor-patient relationship.
\end{abstract}

Keywords: ComplementaryMedicine; Conventional Medicine; Acupuncture; Massage; Herbal.

\section{PENDAhUluan}

Pemerintah Indonesia telah menyediakan pelayanan kesehatan pada pusat kesehatan masyarakat yang dari waktu ke waktu menunjukkan peningkatan dalam kualitas layanan. Pemerintah Kota Surabaya sejak beberapa tahun terakhir ini telah menambahkan pelayanan kesehatan komplementer pada beberapa pusat kesehatan masyarakat, yaitu yang dilaksanakan oleh tenaga kesehatan lulusan Program Diploma 3 dan 4 Pengobat Tradisional. Perpaduan pelayanan antara pengobatan konvensional dan pengobatan komplementer menarik minat masyarakat, antara lain karena masih populernya sistem pengobatan komplementer (Dang dkk, 2002). Pelaksanaan pelayanan terpadu semacam itu mulai menimbulkan berbagai masalah baru, terutama yang berkaitan dengan 
efektivitas dan efek samping yang mungkin terjadi, yang apabila tidak diantisipasi akan menimbulkan masalah kesehatan yang merugikan. Masalah pemakaian secara bersamaan antara obat konvensional dan obat komplementer menjadi makin kompleks a pabila digunakan oleh penderita penyakit degenerative dan sindroma metabolik, seperti penyakit diabetes, kardiovaskuler, susunan saraf pusat, persendian, osteoporosis, dan la in sebagainya. Faktor penyebab utama keadaan itu adalah kurangnya pengetahuan dan pengalaman tenaga medis sehingga tidak dapat memberikan komunikasi, informasi, da n edukasi (KIE) yang sesuai dengan harapan pasien. Keadaan ini membuat pasien tidak mematuhi nasehat dokter, misalnya tidak minum obat pemberian dokter karena sudah mengonsumsi ramuan obat tradisional, tidak menganut pola hidup sehat, kesalahan pemilihan jenis pengobatan komplementer y ang sesuai, dan la in-lain.

Sementara itu, kemajuan pesat dalam sistem pengobatan komplementer seharusnya memberikan kesempatan bagi setiap orang untuk mengobati dan mencegah penyakit. Berbagai penelitian telah dilakukan terhadap berbagai tanaman obat, penyelenggaraan akupunktur, pijat, sehingga pengaplikasian untuk hidup sehat dapat dipertanggungjawabkan secara ilmiah.

Sistem pengobatan tradisional Indonesia yang ditemukan dan digunakan sejak berabad - abad lalu, mempunyai kumpulan ramuan obat bahan alam yang tidak terhitung ragam dan jumlahnya. Melalui kajian terhadap ramuan dan bahan baku kandungannya, diketahui bahwa bagian terbesar berkhasiat untuk mencegah penyakit, dan hal itu sudah didukung oleh penelitianilmiah.

Mengingat belum semua pusat kesehatan masyarakat di Kota Surabaya dilengkapi dengan fasilitas pelayanan terpadu tersebut, maka adalah merupakan tanggung ja wab sivitas akademika Fakultas Farmasi Universitas Airlangga untuk merancang dan melaksanakan program pengabdian masyarakat yang memadukan pengobatan konvensional dan komplementer secara benar.

Kalau program terdahulu selalu berfokus pada pengobatan konvensional, maka sudah tiba saatnya untuk melakukan perubahan disain, yaitu sebagai antisipasi pada tingginya minat masyarakat terhadap pela yanan kesehatan komplementer. Perubahan disain perlu mempertimbangkan pelaksanaan program yang dilakukan dalam lebih dari satu pertemuan. Dengan demikian a kan terjalin hubungan yang lebih erat antara tenaga kesehatan dan pasien, yang akan menunjang optimalisasi pengobatan. Optimalisasi itu dirancang mela lui kegiatan pelayanan kesehatan konv ensional dan komplementer terpadu yang melibatkan dosen dan mahasiswa secara sistematis, berkesinambungan, dan terprogram, sehingga akan memberikan dampak optimalterhadap peningkatan kesehatan masyarakat.

Melalui pertimbangan pelaksanaan pengobatan komplementer bersama pengobatan konvensional bagi masyarakat yang sudah berlangsung pada pusat kesehatan masyarakat, maka program pengabdian masyarakat ini bertujuan untuk menyelenggarakan pelayanan kesehatan secara terpadu antara pengobatan konvensional dan komplementer untuk mengoptimalkan pemahaman masyarakat tehadap pelayanan terpadu tersebut. Program pelayanan pengobatan konvensional dirancang dalam bentuk cera mah dan konsultasi kesehatan secara pribadi dengan fokus utama pada kepatuhan pelaksanaan hasil pemeriksaan kesehatan petugas pusat kesehatan masyarakat setempat, termasuk kepatuhan minum obat, pengaturan pola hidup sehat yaitu diet, olahraga dan istirahat. Program pelayanan pengobatan komplementer dirancang dalam bentuk pemilihan tanaman obat, akupunktur dan pijat yang sesuai dengan kondisi kesehatan pasien.

Pelaksanaan Program Pengabdian Masyarakat Fakultas Farmasi Universitas Airla ngga ini diadakan bagi warga lanjut usia RT 2 RW IV Karang Gayam Teratai, Pacar Keling, Keca matan Tambaksari, Kota Surabaya selama empat kali pertemuan dalamkurun wa ktu 1 (satu) bulan dalam 4 (empat) ka li pertemuan, yaitu Bulan Juli 2019. Warga usia lanjut daerah ini merupakan wila yah dengan tingkat pemahaman tentang pola hidup sehat yang rendah dan banyak menderita beberapa penyakit degenerative. Program diadakan sebagai kelanjutan dari a ktivitas bakti sosial yang sudah dilakukan di kawasan tersebut oleh sivitas akademika Program Studi Pengobat Tradisional Fakultas Vokasi Universitas Airlangga. Warga lanjut usia tersebut bersedia mengikuti program pengabdian masyarakat pengobatan terpadu yang ditawarkan Fakultas Farmasi Universitas Airla ngga dan menyatakan kesediaan menjadi warga binaan fakultas. Melalui program ini diharapkan pemahaman warga terhadap program kesehatan konvensional dan komplementer meningkat, dan dapat dilaksanakan bagi peningkatan kesehatan diri, keluarga dan masyarakat. Peningkatan ini diharapkan dapat meningkatkan kualitas hidup pada usia la njut.

\section{METODE}

Kegiatan ini melibatkan mahasiswa, a lumni Fakultas Farmasi dan Program Diploma 3 dan 4 Pengobat Tradisional Fakultas Vokasi Universitas Airlangga, dokter medis, sarja na farmasi a poteker, a hli pijat dan a kupunktur, yang mempunyai kompetensi pengobatan konvensional, pengobatan herbal dan obat tradisional. Peserta berjumlah 30 orang warga binaan kelompok lanjut usia RT 2 RW IV Karang Ga yam Teratai, Pacar Keling, Kecamatan Tambaksari, yang sudah pemah mengikuti kegiatan bakti sosial Universitas Airlangga sebelumnya, dengan kriteria u tama kesediaan mengikuti seluruh rangkaian kegiatan pada program pengabdian masyarakat.

\section{Program tersusunatas:}

Penyuluhan awal, dengan materiy ang terdiri atas

- pola hidup sehat: pentingnya pemilihan diet sehat, istirahat yang cukup minimum 6 jam sehari, dan berola hraga setiaphari minimum selama 30 menit. 
- pengobatan konvensional: pentingnya kepatuhan minum obat sesuai den gan petunjuk dokter.

- pengobatan komplementer: manfaat, jenis, cara pemilihan.

\section{Pelaksanaan tindakan bagipasien terpilih:}

Pertemuan ke 1 minggu ke 1: Monitoring a walkondisi kesehatan umum:

- pemeriksaan kadar gula, kolesterol, a sam urat dalam darah acak, pembahasan pengobatan yang sudah dilaksanakan di Pusat Pelayanan Kesehatan melalui tanya jawab untuk menggali problema kesehatan dan keluhan pasien

- Memberikan saran tindakan yang diperlukan berdasarkan pedoman pengobatan konvensional

- Penetapan pemberian ramuan herbal, terapi pijat, akupunktur.
Pertemuan ke 2 minggu ke 2 dan pertemuan ke 3 minggu ke 3 adalah diskusi kelompok dan konsultasi peserta, pelaksanaan tindakan akupunktur dan pijat yang sudah ditetapkan. Pertemuan ke 4 minggu ke 4: Penyuluhan dan monitoring kesehatan akhir, berupa diskusi hasil dan konsultasi, pemeriksaan tekanan darah, kadar gula, kolesterol da n a sam urat darah.

Tidak dilakukan monitoring dari rumah ke rumah peserta karena keberatan mereka dalam pengaturan ja dwal kunjungan dan keterbatasan petugas.

Adapun alur pelaksanaan program di la pangan adalah sebagaiberikut:

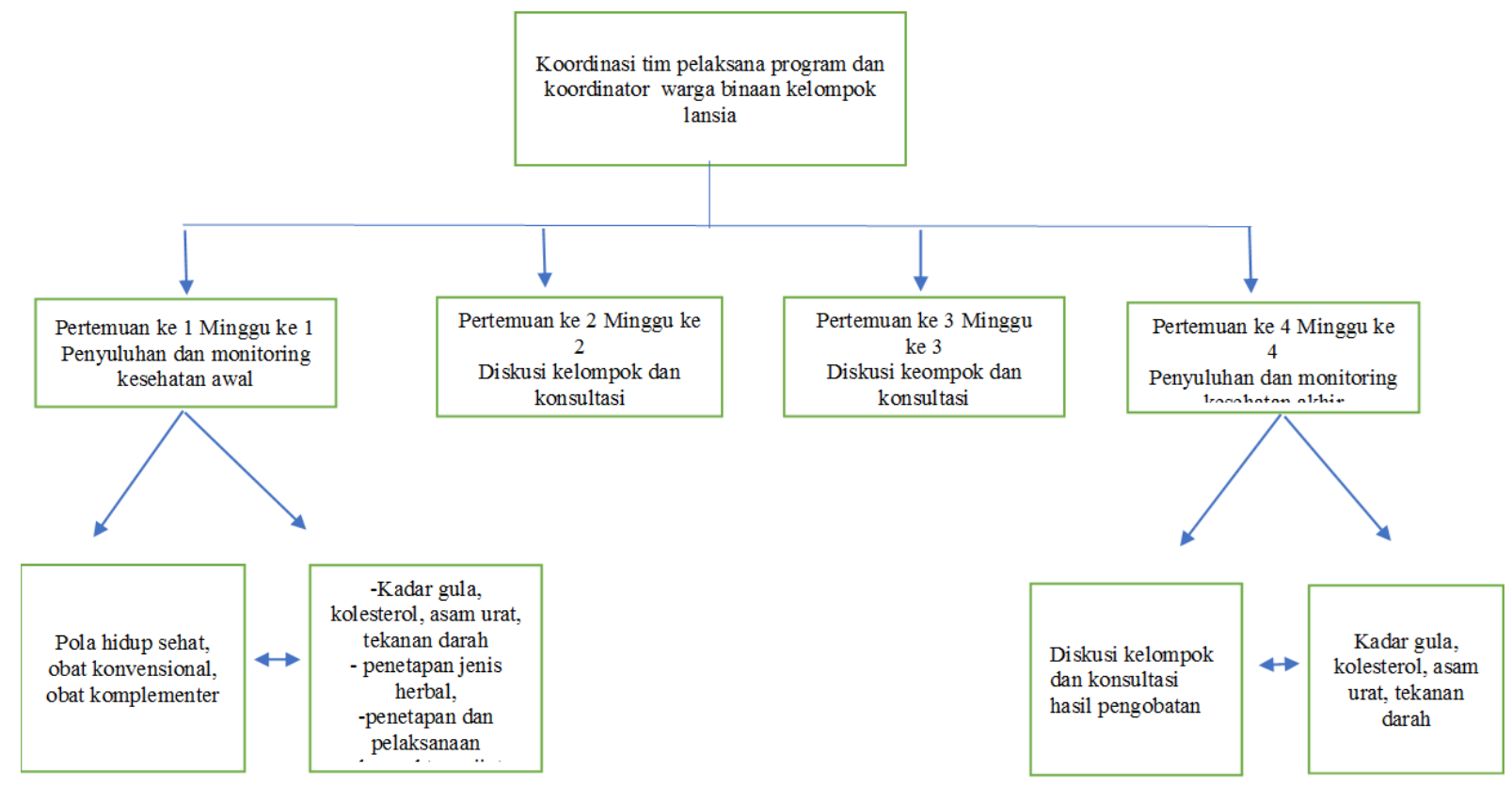

Gambar 1. Alur pela ksanaan programpelayanan kesehatan konvensional dan komplementer terpadu.

\section{HASIL DAN PEMBAHASAN}

Peserta berjumlah 30 orang, yang terdiri dari 6 orang pria dewasa dan 24 orang wanita dewasa. Semua peserta mengalami berbagai gangguan kesehatan penyakit kronik, yaitu diabetes mellitus, tekanan darah tinggi, kadar a sam urat tinggi, kadar kolesterol darah tinggi (Tabel1).
Pasien termuda berusia 35 tahun dan yang tertua 79 tahun. Pasien dengan rentang usia 33 - 50 tahun berjumlah 4 orang, rentang usia $51-65$ tahun berjumlah 14 orang, rentang usia 66 - 80 tahun berjumlah 12 orang.

Tabel 1. Daftar Nama dan Catatan Kesehatan Pasien Sebelum Perlakuan pengobatan.

\begin{tabular}{|c|c|c|c|c|c|}
\hline no & Umur & $\begin{array}{l}\text { Masalah } \\
\text { kesehatan }\end{array}$ & obat & Pemeriksaan & Rekomendasi \\
\hline 1 & 68 & $\begin{array}{l}\text { Gula darah dan } \\
\text { kolesterol tinggi }\end{array}$ & $\begin{array}{l}\text { Injeksi } \\
\text { insulin : } 2 \\
\text { kalisehari } \\
\text { Obat } \\
\text { kolesterol }\end{array}$ & $\begin{array}{l}\text { BB : } 74 \\
\text { TD : } 115 / 70 \\
\text { GD: } 501 \\
\text { AU: } 7,1 \\
\text { Kol: } 385 \mathrm{mg} / \mathrm{dL}\end{array}$ & $\begin{array}{l}\text { Stop teh kemasan } \\
\text { Brotowali } 3 \text { xseminggu } \\
\text { Pare kecil } 2 \text { x seminggu } \\
\text { Putih telur boleh tiap hari } \\
\text { Kuning telurkura ngi menjadi } \\
2 \text { x seminggu }\end{array}$ \\
\hline 2 & 51 & $\begin{array}{l}\text { Kolesterol tinggi } \\
\text { vertigo }\end{array}$ & - & $\begin{array}{l}\text { BB : } 66 \\
\text { TD } 130 / 70\end{array}$ & $\begin{array}{l}\text { Olahraga } 3 \text { xseminggu } \\
\text { Stop gorengan,jeroan }\end{array}$ \\
\hline
\end{tabular}




\begin{tabular}{|c|c|c|c|c|c|}
\hline & & & & $\begin{array}{l}\text { GD: } 117 \\
\text { AU: } 6,8 \\
\text { Kol: } 348\end{array}$ & $\begin{array}{l}\text { Banyak makan sayur, buah } \\
\text { Ba wang putih } 1 \text { siung sehabis } \\
\text { makan/hari }\end{array}$ \\
\hline 3 & 59 & & $\begin{array}{l}\text { Simvastatin } \\
10 \mathrm{mg}\end{array}$ & $\begin{array}{l}\text { BB : } 74 \\
\text { TD } 130 / 89 \\
\text { GD: } 95 \\
\text { AU: } 5.8 \\
\text { Kol: } 180\end{array}$ & $\begin{array}{l}\text { Makan sayur, buah pepaya, } \\
\text { Kurangikopi, teh, gula, nangka, tape }\end{array}$ \\
\hline 4 & 66 & $\begin{array}{l}\text { Kolesterol tinggi } \\
\text { Gula darah tinggi }\end{array}$ & $\begin{array}{l}\text { Obat dari } \\
\text { rumah sakit }\end{array}$ & $\begin{array}{l}\text { BB }: 49 \\
\text { TD } 110 / 80 \\
\text { GD: } 205 \\
\text { AU: } 7,4 \\
\text { Kol: } 383\end{array}$ & $\begin{array}{l}\text { Pakai minyak kedelai } \\
\text { Stop gorengan } \\
\text { Konsumsi sayur kelor } \\
\text { Konsumsi buah } \\
\text { Ba wang putih diracik dalam sa mbal }\end{array}$ \\
\hline 5 & 60 & & - & $\begin{array}{l}\text { BB : } 60 \\
\text { TD }: 130 / 80 \\
\text { GD: } 168 \mathrm{mg} / \mathrm{dL} \\
\text { AU: } 3,1 \\
\text { Kol: } 133\end{array}$ & $\begin{array}{l}\text { Olahraga, berjemur dibawah sinar } \\
\text { matahari } 30 \text { menit tiap hari } \\
\text { Konsumsi putih telur boleh tiap hari } \\
\text { Kuning telur } 2 \times \text { seminggu saja } \\
\text { Air putih } 1,51 / \text { hari }\end{array}$ \\
\hline 6 & 62 & & & $\begin{array}{l}\text { BB }: 62 \\
\text { TD }: 140 / 80 \\
\text { GD: } 137 \\
\text { AU: } 7,7 \\
\text { Kol: } 189\end{array}$ & $\begin{array}{l}\text { Olahraga/berjemur dibawah sinar } \\
\text { matahari } 30 \text { menit tiap hari } \\
\text { Kurangi gorengan, nasi } \\
\text { Makan serbuk jintanhitam } 1 \text { sendok } \\
\text { teh tiap hari }\end{array}$ \\
\hline 7 & 59 & Asam urat tinggi & & $\begin{array}{l}\text { BB }: 60 \\
\text { TD }: 120 / 80 \\
\text { GD: } 88 \\
\text { AU: } 8,4 \\
\text { Kol: } 128\end{array}$ & $\begin{array}{l}\text { Ola hraga, } 1 / 2-1 \text { jam jalan kaki setiap } \\
\text { hari } \\
\text { Stop bakso, empal, soto, daging, } \\
\text { udang, } \\
\text { Makan sayur kelor, kenikir, kembang } \\
\text { turi, da un pepaya } \\
\text { Teh daun salam } 5 \text { lembar dalam } 500 \\
\text { mlair } 3 \text { x seminggu a } 250 \mathrm{ml}\end{array}$ \\
\hline 8 & 53 & $\begin{array}{l}\text { Pegal } \\
\text { Tekanandarah } \\
\text { tinggi } \\
\text { la mbung }\end{array}$ & amlodipin & $\begin{array}{l}\text { BB : } 60 \\
\text { TD: } 140 / 89 \\
\text { GD: } 108 \\
\text { AU: } 4,6 \\
\text { Kol: } 128\end{array}$ & $\begin{array}{l}\text { Hindari makanan asam } \\
\text { Olahraga tiap hari }\end{array}$ \\
\hline 9 & 56 & & & $\begin{array}{l}\text { BB : } 54 \\
\text { TD: } 130 / 80 \\
\text { GD: } 93 \\
\text { AU: } 4,7 \\
\text { Kol: } 187\end{array}$ & $\begin{array}{l}\text { Olahraga tiap hari, berjemur dibawah } \\
\text { sinar matahari } \\
\text { Serbuk jintan hitam satu sendok teh } \\
\text { tiap hari } \\
1 \text { siung ba wang putih segar/hari }\end{array}$ \\
\hline 10 & 59 & & & $\begin{array}{l}\text { BB : } 72 \\
\text { TD }: 140 / 100 \\
\text { GD: } 283 \\
\text { AU: } 46,0 \\
\text { Kol: } 309\end{array}$ & $\begin{array}{l}\text { Konsultasidokter untuk obat penurun } \\
\text { kadar kolesterol } \\
\text { Obat tekanan darah tinggi } \\
\text { Stop gorengan } \\
\text { Serbuk Jintan hitam } 1 \text { sendok teh tiap } \\
\text { hari } \\
\text { Tusuk jarum }\end{array}$ \\
\hline 11 & 66 & $\begin{array}{l}\text { Gula darahttingi } \\
\text { 2014: suntik } \\
\text { insulin }\end{array}$ & $\begin{array}{l}\text { Insulin } 2 \mathrm{x} \\
\text { sehari } \\
\text { Obat cina } \\
\text { untuk } \\
\text { kolesterol }\end{array}$ & $\begin{array}{l}\text { BB : } 66 \\
\text { TD: } 100 / 70 \\
\text { GD: } 283 \\
\text { AU: } 5,9 \\
\text { Kol: } 256\end{array}$ & $\begin{array}{l}\text { Kenda likan diet } \\
\text { Ba wang puth } 1 \text { siung, serbuk jintan } \\
\text { hitam } 1 \text { sendok teh setiap hari }\end{array}$ \\
\hline 12 & 46 & $\begin{array}{l}\text { Sakit kepala } \\
\text { hiperkolesterol }\end{array}$ & & $\begin{array}{l}\text { BB : } 69 \\
\text { TD }: 100 / 70 \\
\text { GD: } 83 \\
\text { AU: } 4,9 \\
\text { Kol: } 271 \\
\end{array}$ & $\begin{array}{l}\text { Stop gorengan } \\
\text { Olahraga } 3 \mathrm{x} \text { seminggu } \\
\text { Bawang putih } 1 \text { siung/hari } \\
\text { Perasan kunyit } 3 \text { kali seminggu a } 150 \\
\text { ml }\end{array}$ \\
\hline
\end{tabular}




\begin{tabular}{|c|c|c|c|c|c|}
\hline & & & & & \\
\hline 13 & 74 & & & $\begin{array}{l}\text { BB }: 46 \\
\text { TD }: 100 / 70 \\
\text { GD: } 129 \\
\text { AU: } 6,3 \\
\text { Kol: } 182 \\
\end{array}$ & $\begin{array}{l}\text { Olahraga, berjemur dibawah sinar } \\
\text { matahari } \\
\text { Rebusan kacang hijau } 250 \mathrm{ml} 3 \mathrm{x} \\
\text { seminggu }\end{array}$ \\
\hline 14 & 79 & Nyeri lutut & vitamin & $\begin{array}{l}\text { BB }: 55 \\
\text { TD }: 115 / 80 \\
\text { GD: } 86 \\
\text { AU6,4 } \\
\text { Kol: } 261\end{array}$ & $\begin{array}{l}\text { Stop gulai, } \\
\text { kuning telur } 1 \text { x seminggu, putih telur } \\
\text { setiap hari } \\
\text { Ja lan pagi setiap hari } \\
\text { Rebusan kunyit } 3 \text { kali seminggu a } 250 \\
\text { ml } \\
\text { Serbuk jintan hitam } 1 \text { sendok teh/hari }\end{array}$ \\
\hline 15 & 76 & & & $\begin{array}{l}\text { BB : } 63 \\
\text { TD }: 120 / 80 \\
\text { GD: } 102 \\
\text { AU5,8 } \\
\text { Kol: } 242\end{array}$ & $\begin{array}{l}\text { Stop santan dalam lodeh } \\
\text { Stop kuning telor, udang, cumi, soto, } \\
\text { bakso } \\
\text { Jamu kunyit asam, sinom } 3 \text { kali } \\
\text { seminggu a } 250 \mathrm{ml} \\
\text { Kurangi gula } \\
\text { Sayur kelor,kenikir, turi, da un pepaya } 3 \\
\text { kaliseminggu }\end{array}$ \\
\hline 16 & 54 & $\begin{array}{l}\text { Kepala berat } \\
\text { Lutut sakit }\end{array}$ & & $\begin{array}{l}\text { BB : } 65 \\
\text { TD: } 100 / 60 \\
\text { GD: } 97 \\
\text { AU: } 5,8 \\
\text { Kol: } 317\end{array}$ & $\begin{array}{l}\text { Stop gorengan } \\
\text { Olahraga } 3 \text { x seminggu } \\
\text { Bawang putih } 1 \text { siung/hari }\end{array}$ \\
\hline 17 & 51 & & & $\begin{array}{l}\text { BB : } 60,5 \\
\text { TD } 120 / 80 \\
\text { GD: } 230 \\
\text { AU: } 7,3 \\
\text { Kol: } 194\end{array}$ & $\begin{array}{l}\text { Serbuk jintan hitam satu sendok } \\
\text { teh/hari }\end{array}$ \\
\hline 18 & 51 & Kolesterol tinggi & - & $\begin{array}{l}\text { BB : } 52 \\
\text { TD } 80 / 60 \\
\text { GD: } 94 \\
\text { AU: } 6,6 \\
\text { Kol: } 292\end{array}$ & $\begin{array}{l}\text { Pakai minyak kedelai } \\
\text { Stop gorengan } \\
\text { Sayur kenikir, kelor, daun pepaya, } \\
\text { kembang turi, bayam 3x seminggu } \\
\text { Stop daging sapi, rambak, kulit }\end{array}$ \\
\hline 19 & 57 & $\begin{array}{l}\text { Tekanandarah } \\
\text { tinggi }\end{array}$ & $\begin{array}{l}\text { Daun moris } \\
\text { untuk } \\
\text { kolesterol }\end{array}$ & $\begin{array}{l}\text { BB : } 64 \\
\text { TD } 140 / 70 \\
\text { GD: } 163 \\
\text { AU: } 4,9 \\
\text { Kol: } 169\end{array}$ & $\begin{array}{l}\text { Kurangiberatbadan } \\
\text { Kurangi nasi } \\
\text { Kunyit parut seminggu tiap hari, } \\
\text { selanjutnya } 3 \text { x seminggu } \\
\text { Jintan hitam } 1 \text { senok teh/hari }\end{array}$ \\
\hline 20 & 67 & & $\begin{array}{l}\text { Obat tekanan } \\
\text { darah tinggi } \\
\text { Kolesterol } \\
\text { Obat nyeri } \\
\text { tulang }\end{array}$ & $\begin{array}{l}\text { BB }: 86 \\
\text { TD } 110 / 80 \\
\text { GD: } 96 \\
\text { AU: } 8,2 \\
\text { Kol: } 281\end{array}$ & $\begin{array}{l}\text { Kurangiberatbadan } \\
\text { Kurangi nasi } \\
\text { Kunyidiparut tiap hari selama } \\
\text { seminggu a } 150 \mathrm{ml} \text {, selanjutnya } 3 \text { kali } \\
\text { seminggu } \\
\text { Serbuk jintan hitam } 1 \text { sendok teh/hari }\end{array}$ \\
\hline 21 & 78 & $\begin{array}{l}\text { Kolesterol } \\
\text { Tekanan daraah } \\
\text { tinggi }\end{array}$ & -amlodipin & $\begin{array}{l}\text { BB }: 47 \\
\text { TD }: 120 / 70 \\
\text { GD: } 98 \\
\text { AU: } 5,9 \\
\text { Kol: } 229\end{array}$ & $\begin{array}{l}\text { Kurangigorengan } \\
\text { Herbaluntuk hipertensi: bawang puth1 } \\
\text { siung/hari }\end{array}$ \\
\hline 22 & 75 & $\begin{array}{l}\text { Ttekanan darah } \\
\text { tinggi }\end{array}$ & amlodipin & $\begin{array}{l}\text { BB }: 59 \\
\text { TD }: 150 / 70 \\
\text { GD } 119 \\
\text { AU: } 7,6 \\
\text { Kol: } 140\end{array}$ & $\begin{array}{l}\text { Olahraga tiap hari } \\
\text { Diet } \\
\text { Konsumsi herbal: bawang putih } 1 \\
\text { siung/hari }\end{array}$ \\
\hline
\end{tabular}




\begin{tabular}{|c|c|c|c|c|c|}
\hline 23 & 75 & $\begin{array}{l}\text { Linu } \\
\text { Sakit kepala }\end{array}$ & & $\begin{array}{l}\text { BB : } 59 \\
\text { TD }: 140 / 80 \\
\text { GD: } 339 \\
\text { AU: } 9,5 \\
\text { Kol: } 169\end{array}$ & $\begin{array}{c}\text { Stop gorengan } \\
\text { Kurangigaram }\end{array}$ \\
\hline 24 & 45 & & & $\begin{array}{l}\text { BB : } 60 \\
\text { TD: } 120 / 80 \\
\text { GD: } 107 \\
\text { AU: } 4,8 \\
\text { Kol: } 228\end{array}$ & $\begin{array}{l}\text { Susu rendah lemak } \\
\text { Kurangibakso } \\
\text { Daun salam5 lembar, air } 500 \text { mlair, } 3 \\
\text { kaliseminggu a } 250 \mathrm{ml} \\
1 \text { sendok teh serbuk jintan hitam tiap } \\
\text { hari } \\
\text { pijat }\end{array}$ \\
\hline 25 & 60 & $\begin{array}{l}\text { Gula darah dan } \\
\text { kolesterol tinggi }\end{array}$ & & $\begin{array}{l}\text { BB : } 59 \\
\text { TD: } 120 / 80 \\
\text { GD: } 129 \\
\text { AU: } 5,6 \\
\text { Kol: } 221\end{array}$ & $\begin{array}{l}\text { Susu melia teruskan } \\
\text { Ba wang putih } 1 \text { siung/hari } \\
\text { Pare kecil parut } 2 \times \text { seminggu } \\
\text { Putih telus setiap hari }\end{array}$ \\
\hline 26 & 48 & Gula darah tinggi & $\begin{array}{l}\text { Metformin } \\
\text { utk diabetes, } \\
\text { sekarang } \\
\text { sudahstop }\end{array}$ & $\begin{array}{l}\text { BB : } 50,5 \\
\text { TD }: 190 / 100 \\
\text { GD: } 206 \\
\text { AU: } 5,3 \\
\text { Kol: } 190\end{array}$ & $\begin{array}{l}\text { Pengaturan diet } \\
\text { Kurangikarbohidrat, gula, makanan } \\
\text { instan } \\
\text { Daun salam5 lembar, rebus dalam } 500 \\
\text { mlair, } 3 \text { kaliseminggu a } 250 \mathrm{ml} \\
1 \text { sendok tehjintan hitamtiap hari }\end{array}$ \\
\hline 27 & 66 & $\begin{array}{l}\text { Kolesterol, asam } \\
\text { urat tinggi }\end{array}$ & & $\begin{array}{l}\text { BB }: 65 \\
\text { TD: } 140 / 80 \\
\text { GD: } 140 \\
\text { AU: } 7,1 \\
\text { Kol: } 283\end{array}$ & $\begin{array}{l}\text { stop bakso, soto, usus, buncis, ka cang } \\
\text { tanah } \\
\text { Konsumsi sayur kenikir, kembang turi, } \\
\text { daun pepaya } \\
\text { Ba wang putih } 3 \text { siung buat sambal/hari }\end{array}$ \\
\hline 28 & 61 & & & $\begin{array}{l}\text { BB }: 63 \\
\text { TD }: 100 / 80 \\
\text { GD: } 125 \\
\text { AU: } 7,4 \\
\text { Kol: } 175\end{array}$ & $\begin{array}{l}\text { Jintan hitam 1 sendok teh tiap hari } \\
\text { Berjemur dibawah sinar matahari tiap } \\
\text { hari } 30 \text { menit } \\
\text { pijat }\end{array}$ \\
\hline 29 & 37 & & & $\begin{array}{l}\text { BB : } \\
\text { TD }: 120 / 80 \\
\text { GD: } 109 \\
\text { AU: } 7,4 \\
\text { Kol: } 186\end{array}$ & $\begin{array}{l}\text { Stop mengonsumsi kulit ayam dan } \\
\text { makanan berlemak sejenis } \\
\text { Minum teh tawar } \\
\text { akupunktur }\end{array}$ \\
\hline 30 & 35 & & & $\begin{array}{l}\text { BB : } \\
\text { TD : } 90 / 70 \\
\text { GD: } 118 \\
\text { AU: } 8,2 \\
\text { Kol: }\end{array}$ & $\begin{array}{l}\text { Da un salam5 lembar dalam 500mlair } \\
3 \text { x seminggu a } 250 \mathrm{ml} \\
\text { a kupunktur }\end{array}$ \\
\hline
\end{tabular}

Keterangan:

$\mathrm{BB}=$ berat badan $(\mathrm{Kg})$

$\mathrm{TD}=$ tekanan darah $(\mathrm{mmHg}$

$\mathrm{GD}=$ gula darah $(\mathrm{mg} / \mathrm{dL})$
$\mathrm{AU}=$ a sam urat darah $(\mathrm{mg} / \mathrm{dL})$

Kol = kolesterol darah $(\mathrm{mg} / \mathrm{dL})$

$\mathrm{AKP}=$ akupunktur

$\mathrm{Hr}=$ hari 
Tabel 3. Hasil Pemeriksaan Awal Tekanan Da rah, Kadar Gula, Asam Urat dan Kolesterol yang Melebihi Batas Normal Sebelum Perla kuan Pengobatan.

\begin{tabular}{|c|c|c|c|c|c|}
\hline $\begin{array}{l}\text { No } \\
\text { pasien }\end{array}$ & $\begin{array}{l}\text { Tekanan darah } \\
<130 / 80 \mathrm{~mm} \\
\mathrm{Hg}\end{array}$ & $\begin{array}{l}\text { Kadargula darah } \\
<100 \mathrm{mg} / \mathrm{dL}\end{array}$ & $\begin{array}{l}\text { Kadara samurat } \\
<6 \mathrm{mg} / \mathrm{dL}\end{array}$ & $\begin{array}{l}\text { Kadarkolesterol } \\
<200 \mathrm{mg} / \mathrm{dL}\end{array}$ & $\begin{array}{l}\text { Jumlah profil } \\
\text { darah tidak } \\
\text { normal (melebihi } \\
\text { batas) } \\
\end{array}$ \\
\hline 1 & & $\mathrm{~V}$ & $\mathrm{~V}$ & $\mathrm{~V}$ & 3 \\
\hline 2 & $\mathrm{~V}$ & $\mathrm{~V}$ & $\mathrm{~V}$ & $\mathrm{~V}$ & 4 \\
\hline \multicolumn{6}{|l|}{3} \\
\hline 4 & & $\mathrm{~V}$ & $\mathrm{~V}$ & $\mathrm{~V}$ & 3 \\
\hline 5 & $\mathrm{~V}$ & $\mathrm{~V}$ & & & 2 \\
\hline 6 & $\mathrm{~V}$ & $\mathrm{~V}$ & $\mathrm{~V}$ & & 3 \\
\hline 7 & & & $\mathrm{~V}$ & & 1 \\
\hline 8 & $\mathrm{~V}$ & $\mathrm{~V}$ & & & 2 \\
\hline 9 & $\mathrm{~V}$ & & & & 1 \\
\hline 10 & $\mathrm{~V}$ & $\mathrm{~V}$ & $\overline{\mathrm{V}}$ & $\overline{\mathrm{V}}$ & 4 \\
\hline 11 & & $\mathrm{~V}$ & & $\mathrm{~V}$ & 2 \\
\hline 12 & & & & $\mathrm{~V}$ & 1 \\
\hline \multicolumn{6}{|l|}{13} \\
\hline \multicolumn{6}{|l|}{14} \\
\hline 15 & & $\mathrm{~V}$ & & $\mathrm{~V}$ & 2 \\
\hline 16 & & & & $\mathrm{~V}$ & 1 \\
\hline \multicolumn{6}{|l|}{17} \\
\hline \multicolumn{6}{|l|}{18} \\
\hline \multicolumn{6}{|l|}{19} \\
\hline 20 & & & $\mathrm{~V}$ & $\mathrm{~V}$ & 2 \\
\hline 21 & & & & $\mathrm{~V}$ & 1 \\
\hline 22 & $\mathrm{~V}$ & $\overline{\mathrm{V}}$ & $\mathrm{V}$ & & 3 \\
\hline 23 & $\mathrm{~V}$ & $\mathrm{~V}$ & $\mathrm{~V}$ & & 3 \\
\hline 24 & & $\overline{\mathrm{V}}$ & & $\mathrm{V}$ & 2 \\
\hline 25 & & $\mathrm{~V}$ & & $\mathrm{~V}$ & 2 \\
\hline 26 & $\mathrm{~V}$ & $\mathrm{~V}$ & & & 2 \\
\hline \multicolumn{6}{|l|}{27} \\
\hline 28 & & $\mathrm{~V}$ & $\mathrm{~V}$ & & 2 \\
\hline \multicolumn{6}{|l|}{29} \\
\hline \multicolumn{6}{|l|}{30} \\
\hline Total & 9 & 15 & 10 & 12 & 46 \\
\hline
\end{tabular}

Keterangan:

teka nan darah normal $<130 / 80 \mathrm{mmHg}$.

Kadar a samurat dalam serum darah $<6 \mathrm{mg} / \mathrm{dL}$

Kadar kolesterol total $<200 \mathrm{mg} / \mathrm{dL}$

Kadar gula darah $<100 \mathrm{mg} / \mathrm{dL}$

(Sumber American Diabetes Association, dan Perhimpunan Rematologi Indonesia).

Tabel 3 menunjukkan data jumlah peserta dengan 1 kriteria melewati batas normal berjumlah 5 orang, peserta dengan 2 kriteria yang melewatibatas nomal 9 orang, dengan 3 kriteria melewati batas nomal 5 orang, sedangkan peserta yang menunjukkan kriteria keseluruhan yang melewati batas normal berjumlah 2 orang.

Jumlah peserta dengan tekanan darah tinggi 9 orang, ka dar gula darah tinggi 15 orang, kadar a sam urat tin ggi 10 orang, dan kadar kolesterol tinggi 12 orang. Data tersebut menunjukkan tidak terdapatnya peserta yang mempunyai profil darah normal.

\section{Penyuluhanawal:}

Materi yang diberikan adalah tentang pola hidup sehat, pengobatan konvensional dan komplementer Materi pola hidup sehat mencakup nutrisi, olahraga, istirahat, pengendalian stres. Materi pengobatan konvensional meliputi kepatuhan pengobatan (tepat obat, tepat waktu, tepat dosis, tepat aturan pakai). Materi pengobatan komplementer mencakup pemanfaatan tanaman obat secara benar, meliputi penetapan jenis tanaman, pemiliha n kualitas, pencucian, pengirisan, penumbukan, perebusan, penyaringan, penyimpanan. Materi akupunktur dan pijat secara umum meliputi manfaat, pemilihan jenis tindakan, beberapa titik akupunktur untuk mempertahankan keadaan sehat. 


\section{Monitoring kesehatan awal}

Monitoring awal kondisi kesehatan umum adalah pemeriksaan tekanan darah, kadar gula acak, kolesterol, asam urat dalam darah, dan pengobatan yang sudah dijalani peserta di Pusat Pelayanan Kesehatan. Problema yang paling mendesak untuk ditanggulangi adalah pola makan. Pasien cenderung membeli makanan, terutama jajanan di jalan (food street), dan men gu tamakan cita ra sa yang enak tanpa memerhatikan segi nutrisi. Konsultasi diberikan berupa saran dan tindakan yang diperlukan berdasarkan pedoman pengobatan konvensional, pola hidup sehat (nutrisi, olahraga rutin, istira hat cukup, pengendalia n stres).

Pelaksanaan tindakan akupunktur dan pijat yang jenisnya sudah ditetapkan oleh tenaga kesehatan pelaksana program mendapatkan respons yang menggembirakan. Pasien menanggapi secara positip dan bersedia menerima tindakan tersebut. Respons semacam ini merupakan awal yang baik bagi tercapainya keadaan sehat karena mendukung tercapainya relaksasi.

Mela lui monitoring awal ini diketahui bahwa peserta memerlukan saran dan tindakan yang ha rus dilakukan melalui konsultasi a tau komunikasi efektif antara tenaga kesehatan-pasien. Setelah mendapatkan pelayanan pengobatan konvensional melalui pusat kesehatan masyarakat setempat, peserta ternyata membutuhkan perhatian dari tenaga kesehatan terhadap masalah kesehatan dan cara penanganan secara berkelanjutan. Sika p kekeluargaan dan ketulu san dalam memberikan konsultasi melalui program ini telah berhasil menciptakan keakraban dan menimbulkan kepercayaan peserta terhadap pelaksana program.

Pemberian ra muan herbal dilakukan melalui penetapan jenis tanaman dan ramuan sesuai kondisi kesehatan peserta,yaitu: (tabel 2)

- Diabetes: buah paria, daun salam, brotowali

- Kolesterol tinggi: ba wang putih, daun sa lam

- Asam urat tinggi: daun salam

- Antioksidan, antiinflamasi: kunyit

- Peningka tan imunitas tubuh: serbuk bijijintan hitam

- Pemenuhan nutrisi: sayur kelor, kenikir, bayam, bunga turi, ka cang hijau

Takaran dan a turan pakai ditetapkan berdasarkan data pemakaian empiris, yaitu dengan jumlah yang dinyatakan dalam helai, buah, biji, sendok teh. Penetapan ini bertujuan memudahkan pasien dalam menyiapkan bahan dan tidak merasa repot menimbang dan mengukur (Tjakraningrat, 2001).
Dasar penetapan jenis herbal adalah yang dapat bersinergi membantu aktivitas obat konvensional, dan yang sudah mempunyai data penelitian ilmiah tentang aktivitas farmakologisnya. Dosis, aturan pakai, cara pemakaian ditetapkan berdasarkan jenis tanaman, tujuan pemakaian, kondisi kesehatan pasien (Badan POM RI, 2005).

Semua peserta harus mematuhi nasehat dokter untuk minum obat sesuai ta karan dan a turan pakai. Konsumsi ra muan herbal dilakukan tidak bersamaan dengan saat minum obat, dimana penetapan waktu disampaikan pada saat konsultasi dengan mempertimbangkan kondisi kesehatan umum peserta.

Penyia pan sedia an herbal dilakukan oleh peserta atas petunjuk tenaga kesehatan yang bertugas, tenutamayang berkaitan dengan pemilihan bahan herbal yang berkualitas, pencucian, pengupasan, pengirisan, penumbukan atau perebusan, penyaringan, pengemasan, dan penyimpanan (Badan POM RI, 2005). Monitoring dan pencatatan dilakukan secara terinci dalam medicalrecord.

Brotowali adalah tanaman obat yang bernama ilmiah Tinospora tuberculata, dan digunakan bagian batangnya. Penggunaan yang menarik dan perlu diperhatikan adalah sebagai antidiabetes, antioksidan, dan antiinflamatori. Beberapa sumber menyebutkan pemanfaatannya juga untuk mengatasi tekanan darah tinggi. Salah satu uji preklinik menyebutkan bahwa air rebusan batang dapat menurunkan kadar gula darah, yaitu dengan cara meningkatkan pengeluaran insulin dari sel beta pankreas (Thomas dkk, 2016).

Paria a dalah pare, yaitu tanaman obat yang bemama ilmia Momordica charantia, dan digunakan secara luas seba gai obat penurun kadar gula darah. Pa re kaya akan kandungan vitamin, mineral dan zat fitokimia. Buah pare kaya kandungan vitamin B1, B2, B3, B9, C, A, E. Mineral yang terkandung di da lamnya adalah $\mathrm{K}, \mathrm{Ca}$, Zinc, ma gnesium, fosfor, zat besi, dan sebagai sumber serat. Aktivitas antioksidan merupakan kerja dari kandungan senyawa golongan fenol, flavonoid, isoflavon, dan terpen. Senyawa yang diduga mempunyai aktivitas penurun kadar gula adalah charantin, cucurbitacin, cucurbitan dan lain-lain. Kerja seny awa tersebut didu ga melalui berbagai cara atau jalur yang berbeda-beda, seperti memperbaiki fungsi sel beta pankreas, merangsang pemakaian glukosa di otot dan di perifer (Joseph \& Jini, 2013). 
Tabel 2. Ta naman Obat dan Ramuan Obat TradisionalPilihan pada Program Pelayanan Kesehatan Konvensional dan Komplementer Terpadu.

\begin{tabular}{|c|c|c|c|c|c|}
\hline \multirow{2}{*}{$\begin{array}{l}\text { Tanaman } \\
\text { Obat/Ramuan }\end{array}$} & \multicolumn{4}{|c|}{ Gangguan Kesehatan } & Catatan \\
\hline & $\begin{array}{l}\text { Kadar gula } \\
\text { darah tinggi } \\
\text { (diabetes) }\end{array}$ & $\begin{array}{l}\text { Kadar } \\
\text { kolesterol tinggi }\end{array}$ & $\begin{array}{l}\text { Kadar asam } \\
\text { urat tinggi }\end{array}$ & Lain-lain & Anjuran: \\
\hline Buah pare & $\mathrm{V}$ & & & & Mengurangi \\
\hline Bawangputih & & $\mathrm{V}$ & & & gula, garam, \\
\hline Daun salam & $\mathrm{V}$ & $\mathrm{V}$ & $\mathrm{V}$ & & pengawet \\
\hline Brotowali & $\mathrm{V}$ & & & & makanan \\
\hline Kunyit & & & & $\begin{array}{l}\text { Mengatasi } \\
\text { peradangan yang } \\
\text { menyebabkan } \\
\text { gangguan } \\
\text { persendian, } \\
\text { analgesik }\end{array}$ & $\begin{array}{l}\text { Mengurangi } \\
\text { makanan } \\
\text { gorengan, } \\
\text { nasi, jeroan, } \\
\text { telur, bakso, } \\
\text { empal, soto }\end{array}$ \\
\hline Jinten hitam & & & & $\begin{array}{l}\text { Meningkatkan } \\
\text { daya tahan tubuh }\end{array}$ & $\begin{array}{l}\text { udang, gulai, } \\
\text { gula, }\end{array}$ \\
\hline $\begin{array}{l}\text { Sayur kelor, } \\
\text { kenikir, bunga } \\
\text { turi, bayam, } \\
\text { kacang hijau }\end{array}$ & & & & $\begin{array}{l}\text { Pemenuhan } \\
\text { kebutuhan serat, } \\
\text { vitamin, mineal }\end{array}$ & $\begin{array}{l}\text { susu, kulit } \\
\text { ayam, } \\
\text { makanan } \\
\text { siap saji }\end{array}$ \\
\hline Minuman pokak & & & & $\begin{array}{l}\text { Mengatasi } \\
\text { gangguan saluran } \\
\text { napas, saluran } \\
\text { cerna, radang } \\
\text { persendian, } \\
\text { sebagai } \\
\text { antioksidan }\end{array}$ & $\begin{array}{l}\text { Berolahraga } \\
\text { secara rutin } \\
\text { Berjemur di } \\
\text { bawah sinar } \\
\text { matahari } \\
\text { Pijat, } \\
\text { akupunkttur }\end{array}$ \\
\hline
\end{tabular}

\section{Catatan:}

Penyia pan obat daritanaman:

- Pare: Buah pare segar berukuran sedang yang sudah dibersihkan, dibuat menjadi jus dan langsung diminum setelah disaring seka li sehari

- Bawang putih: sa tu siung ba wang putih segar sekali sehari

- Da un salam: 5 lembar daun segar direbus dalam 500 ml airhingga mendidih. Diminum 250 ml sekali sehari

- Jintan hitam: serbuk biji sa tu sendok teh diseduh dengan $150 \mathrm{ml}$ air pa nas, aduk dan diminum setiap hari.

- Minuman pokak: dibuat sendiri dengan resep pilihan penderita. Ramuan la ngsung diminum segera setelah selesai dibuat.

- Pera san kunyit: 10-20 cm rimpang kunyit dikupas, diiris tipis, ditumbuk dalam lumpang sambil diberia ir sedikit demi sedikit. Pera s dan minum $150 \mathrm{ml}$ sehari.

Daun salam bernama ilmiah Syzygium polyanthum. Beberapa penelitian telah dilakukan untuk mempelajari aktivitas farmakologik komponen daun salam dalam menurunkan kadar asam urat dalam darah (Andriani \& Chaidir, 2018). Banyak hasil penelitian membuktikan, bahwa tingginya kadar a sam urat memberi a ndil pada timbulnya penyakit la in, seperti penyakit kardiovaskuler dan diabetes.

Berba gai studi ilmiah menunjukkan khasiat daun salam sebagai antihiperglikemik, yang artinya menununkan kadar gula darah. Penelitian menunjukkan bahwa aktivitas itu mungkin terjadi melalui hambatan penyerapan glukosa dari usus dan peningkatan penga mbilan glukosa oleh otot (Widyawati dkk, 2015).

Bawang putih sudah lama dan banyak digunakan seba gai penurun kadar kolesterol dalam darah. Banyak penelitian telah dilakukan, dimana hasillnya menunjukkan kemampuan ekstrak airnya menununkan kadar serum total kolesterol. High density lipoprotein (HDL) tidak mengalami peningkatan, sedangkan low- 
density lipoprotein (LDL) sedikit menurun (Ried dkk, 2013). Pemakaian bawang putih pada umumnya aman, terutama bila dibandingkan dengan obat konvensional.

Jinten hitam a dalah biji tanaman Nigella sativa, yang sudah dipakai berabad lamanya untuk mengatasi berbagai masalah kesehatan. Studi yang sangat luas sudah dilakukan untuk membuktikan aktivitas farmakologi, di a ntaranya a dalah a ktivitas a ntidiabetes, anti kanker, imunomodulator, a nalgesik, antimikroba, antiradang, spasmolitik, bronkodilator, pelindung fungsi organ hati, pelindung fungsi ginjal dan sa luran cerna, antioksidan. Karena kehebatan kekuatan penyembuhannya, maka jinten hitam dinyatakan sebagai obat y ang menempati peringkat tertinggi pada evidence based herbal medicines (Ahmad et al., 2013).

Minuman khas tradisional Indonesia adalah minuman yang dapat disarankan untuk mengatasi berbagai gangguan kesehatan sebagai antiradang, penghilang rasa sakit, antioksidan. Rimpang tanaman Suku Zingiberaceae, seperti jahe, temulawak, kencur, kunyit telah menarik perhatian penelitikarenakhasiatnya yang cukup luas (Beers, 2012; Sethi dkk, 2009).

Kunyit berasal dari tanaman bernama ilmiah Curcuma domestica. Bagian yang digunakan adalah rimpang ta naman. Pemakaiannya untuk mengatasi peradangan, seperti artritis (rematik), sudah didukung melalui hasil penelitian. Pada percobaan dengan hewan percobaan tikus diketahui, bahwa kunyit dapatmengurangi radang kronik dan akut. Khasiat kunir untuk mengatasi tukak (luka) saluran pencernakan makanan telah didukung oleh penelitian ilmiah (Labban, 2014).

Terapi Pijat dan akupunktur dilaksanakan dalam empat ka li pertemuan dalam Bulan Juli 2019 di Balai Rukun Warga. Jenis tera pi dipilih melalui koordinasi dengan tenaga kesehatan yang bertugas, yaitu: untuk pijat adalah full-body massage, head andneck massage, foot /hand massage. Penetapan titik akupunktur dilakukan oleh tenaga kesehatan ahli akupunktur. Pemilihan tinda kan berdasarkan gangguan kesehatan pasien dan untuk mencapai keadaan relaksasi (Michael, 1990). Keadaan relaksasi diperlukan untuk mendapatkan kea daan sehat.

Penyuluhan dan monitoring akhir dilakukan pada minggu ke 4 program. Monitoring dilakukan melalui pengecekan kadar gula darah, ka dar kolesterol, kadar asa $\mathrm{m}$ urat, tekanan darah, serta menanggapi problema dan keluhan pasien.
Ha silmonitoring akhir menunjukkan kondisi kesehatan yang bervariasi, yaitu terdapatnya peserta yang mengalami perbaikan, tetapi ada yang tidak, dan bahkan a da pula yang memburuk. Walaupun demikian, tidak terdapat seorang pun peserta menunjukkan perbaikan pada semua profil darah yang diukur, yaitu tekanan darah, kadar gula, a sam urat dan kolesterol, setelah mematuhi anjuran minum obat yang disa rankan dokter, pengaturan pola hidup sehat, mengonsumsi herbal, melaksanakan tindakan akupunktur atau pijat. Hasil pengamatan pada perlakuan pasien selama 4 kali pertemuan menunjukkan belum terdapatnya pasien yang mengalami perbaikan pada ke 4 kriteria profil darah yang diperiksa. Bahkan beberapa pasien menunjukkan peningkatan kadar melebihi ba tas nomal yang diperkenankan.

Tabel 7 menunjukkan berbagai perubahan yang mencolok pada profil darah setelah perlakuan selama4 minggu. Hasilnya menunjukkan bahwa pola hidup memegang peran yang sangat besar pada keberhasilan pemanfaatan pengobatan konvensional dan komplementer. Peserta no. 1,2 dan 11 melakukan upaya seca ra serius untuk merubah pola makan danberdampak positip pada penurunan kadar gula dan kolesterol darah, yaitu terjadinya penurunan secara drastis, walaupun teka nan darah dan kadar asam urat masih belum normal. Peserta no. 11 mengakui, bahwa pengendalian pola makan terbukti dapat memperbaiki profil darah, wa laupun memang tidak mudah dilakukan.

Apabila jumlah kriteria profil darah yang melewati batas normal sebelum dan sesudah perlakuan dibandingkan, maka diperoleh fakta terjadinya peningkatan jumlah kriteria profil darah yang tidak normal. Peserta dengan 1 kriteria men galami penurunan, jumlah peserta dengan jumlah kriteria 2, 3, dan 4 mengalami peningkatan (Tabel 5). Apabila dibandingkan kriteria profil darah peserta yang melewati batas normal sebelum dan sesudah perlakuan diperoleh fakta terjadinya peningkatan peserta dengan tekanan darah tinggi, gula darah tinggi, dan kolesterol tinggi. Peserta dengan kadar asam urat tinggi mengalami penurunan (Tabel6).

Hal yang teramati melalui interaksi selama 4 kali pertemuan dalam waktu sa tu bulan a dalah terciptanya hubungan yang harmonis antara pelak sana program dan para peserta. Hubungan ini mengindikasikan tercapainya kebutuhan peserta akan terselenggaranya interaksi dengan para pakar kesehatan yang mereka butuhkan selain pemeriksaan rutin yang berlangsung di pusat kesehatan masyarakat.

Tabel 4. Hasil Pemeriksaan Tekanan Darah, Ka dar Gula, Asam Urat dan Kolesterol yang Melebihi Batas Normal Setelah Perlakuan Pengobatan pada Minggu 4.

\begin{tabular}{|l|l|l|l|l|l|}
\hline $\begin{array}{l}\text { No } \\
\text { pasien }\end{array}$ & $\begin{array}{l}\text { Tekanan } \\
\text { darah } \\
<\mathbf{1 3 0 / 8 0 ~} \mathbf{m m} \\
\mathrm{Hg}\end{array}$ & $\begin{array}{l}\text { Kadar gula } \\
\text { darah } \\
\text { Puasa }<\mathbf{1 0 0} \\
\mathbf{m g / d L}\end{array}$ & $\begin{array}{l}\text { Kadar asam urat } \\
\mathbf{6} \mathbf{6} \mathbf{~ m g} / \mathbf{d L}\end{array}$ & $\begin{array}{l}\text { Kadar } \\
\text { kolesterol } \\
<\mathbf{2 0 0} \mathbf{~ m g} / \mathbf{d L}\end{array}$ & $\begin{array}{l}\text { Jumlah profil } \\
\text { darah tidak } \\
\text { normal }\end{array}$ \\
\hline 1 & $\mathrm{~V}$ & $\mathrm{~V}$ & $\mathrm{~V}$ & $\mathrm{~V}$ & 4 \\
\hline 2 & $\mathrm{~V}$ & $\mathrm{~V}$ & & $\mathrm{~V}$ & 3 \\
\hline
\end{tabular}




\begin{tabular}{|c|c|c|c|c|c|}
\hline 3 & & & & & \\
\hline 4 & & $\mathrm{~V}$ & & $\overline{\mathrm{V}}$ & 2 \\
\hline 5 & $\overline{\mathrm{V}}$ & $\bar{V}$ & $\overline{\mathrm{V}}$ & $\bar{V}$ & 4 \\
\hline 6 & $\mathrm{~V}$ & $\mathrm{~V}$ & $\mathrm{~V}$ & $\mathrm{~V}$ & 4 \\
\hline 7 & & & $\bar{V}$ & & 1 \\
\hline 8 & $\overline{\mathrm{V}}$ & $\bar{V}$ & & & 2 \\
\hline 9 & $\mathrm{~V}$ & $\mathrm{~V}$ & & & 2 \\
\hline 10 & $\mathrm{~V}$ & $\mathrm{~V}$ & & $\mathrm{~V}$ & 3 \\
\hline 11 & & $\mathrm{~V}$ & $\mathrm{~V}$ & & 2 \\
\hline 12 & & $\bar{V}$ & & $\bar{V}$ & 2 \\
\hline 13 & & & & & \\
\hline 14 & & & & & \\
\hline 15 & $\overline{\mathrm{V}}$ & & & $\overline{\mathrm{V}}$ & 2 \\
\hline 16 & $\mathrm{~V}$ & $\mathrm{~V}$ & & $\mathrm{~V}$ & 3 \\
\hline 17 & & & & & \\
\hline 18 & & & & & \\
\hline 19 & & & & & \\
\hline 20 & $\bar{V}$ & & $\mathrm{~V}$ & $\overline{\mathrm{V}}$ & 3 \\
\hline 21 & $\mathrm{~V}$ & & $\bar{V}$ & & 2 \\
\hline 22 & $\bar{V}$ & $\mathrm{~V}$ & & & 2 \\
\hline 23 & $\mathrm{~V}$ & $\mathrm{~V}$ & & $\mathrm{~V}$ & 3 \\
\hline 24 & & $\bar{V}$ & & $\bar{V}$ & 2 \\
\hline 25 & $\bar{V}$ & $\overline{\mathrm{V}}$ & & $\overline{\mathrm{V}}$ & 3 \\
\hline 26 & $\mathrm{~V}$ & $\mathrm{~V}$ & & $\mathrm{~V}$ & 3 \\
\hline 27 & & & & & \\
\hline 28 & & & $\mathrm{~V}$ & $\mathrm{~V}$ & 2 \\
\hline 29 & & & & & \\
\hline 30 & & & & & \\
\hline Total & 15 & 16 & 8 & 15 & 54 \\
\hline
\end{tabular}

Keterangan:

teka nan darah normal $<130 / 80 \mathrm{mmHg}$.

Kadar a samurat dalam serum darah $<6 \mathrm{mg} / \mathrm{dL}$

Kadar kolesterol total $<200 \mathrm{mg} / \mathrm{dL}$

Kadar gula darah $<100 \mathrm{mg} / \mathrm{dL}$

(Sumber American Dia betes Association, dan Perhimpunan Rematologi Indonesia).

Tabel 4 menunjukkan data jumlah peserta dengan 1 kriteria melewati batas normal berjumlah 1 orang, peserta dengan 2 kriteria yang melewatibatas nomal 10 orang, dengan 3 kriteria melewati batas nomal 7 orang, sedangkan peserta yang menunjukkan kriteria keseluruhan yang melewati ba tas normal berjumlah 3 orang.
Jumlah peserta dengan tekanan darah tinggi berjumlah 15 orang, kadar gula darah tinggi berjumlah 16 orang, ka dar asam urat tinggi berjumlah 8 orang, kadar kolesterol tinggi berjumlah 15 orang. Da ta ini menunjukkan tidak terdapatnya pasien yang mempunyai profil darah normal.

Tabel 5. Perba ndingan Jumlah Kriteria Profil Darah Peserta y ang Melewati Batas Normal Sebelum dan Sesudah

\begin{tabular}{|l|c|c|l|}
\hline $\begin{array}{l}\text { Jumlah } \\
\text { kriteria }\end{array}$ & Minggu 1(sebelum perlakuan) & $\begin{array}{l}\text { Minggu 4 (sesudah } \\
\text { perlakuan }\end{array}$ & Keterangan \\
\hline 1 & 5 & 1 & menurun \\
\hline 2 & 9 & 10 & meningkat \\
\hline 3 & 5 & 7 & meningkat \\
\hline 4 & 2 & 3 & meningkat \\
\hline
\end{tabular}

Apabila dibandingkan kriteria profil darah yang melewa ti batas nomal sebelum dan sesudah perlakuan peserta diperoleh fakta terjadinya peningkatan peserta dengan tekanan darah tinggi, gula darah tinggi, dan kolesterol tinggi. Peserta dengan kadar a sam urat tinggi mengalami penurunan (Tabel6). 
Tabel 6. Perbandingan Jumlah Gangguan Tekanan Darah, Gula Da rah, Asam Urat dan kolesterol tinggi Peserta Sebelum dan Sesudah Perla kuan.

\begin{tabular}{|l|c|c|l|}
\hline $\begin{array}{l}\text { Profil } \\
\text { darah }\end{array}$ & Minggu 1(sebelumperlakuan) & $\begin{array}{l}\text { Minggu 4 (sesudah } \\
\text { perlakuan }\end{array}$ & Keterangan \\
\hline $\begin{array}{l}\text { Tekanan } \\
\text { darah }\end{array}$ & 9 & 15 & peningkatan \\
\hline Gula darah & 15 & 16 & peningkatan \\
\hline Asam urat & 10 & 8 & penurunan \\
\hline Kolesterol & 12 & 15 & peningkatan \\
\hline
\end{tabular}

Data hasil penelitian menunjukkan peningkatan profil darah yang melebihi batas normal padaa khir penelitian, keberhasila n peserta no 1,2, dan 11 dalam menununkan beberapa profil darah melalui perubahan pola makan, pengakuan peserta no 11 bahwa profil darah normal dapat diperoleh melalui upaya yang kuat. Da ta tersebut membuktikan pentingnya peran pola hidup sehat untuk mencapai kea daan sehat. Pola makan misalnya, dimana mayoritas peserta tidak mewaspadai bahaya mengonsumsi makanan gorengan dan makanan siap saji. Banyak di antara mereka beranggapan bahwa makanan itu tidak berbahaya sepanjang tidak dikonsumsi dalam jumlah berlebihan. Sementara itu, pemahaman tentang istilah jumlah berlebihan pun masih perlu diperbaiki. Hal ini diketahui melalui kebiasaan peserta no. 14 dan 15 yang merasa perlu mengonsumsi telur setiap hari sebagai sumber kekuatan walaupun ka dar kolesterol darah mereka sudah melewati ambang batas yang diperkenankan. Hasil sebuah penelitian ilmiah menunjukkan terjadinya peningkatan jumlah manusia lanjut usia yang sangat cepat di dunia pada abad ini. Peningkatan jumlah itu tentu perlu diikuti dengan peningkatan keadaan sehat. Tekanan darah tinggi sebagai sa lah satu ga ngguan kesehatan pada usia lanjut menjadi penyebab terjadinya komplikasi kardiovaskuler yang secara pasti akan menununkan kualitas hidup. Komplikasi tersebut akan mengganggu fungsi organ vital tubuh lain, dan sela njutnya terjadi penurunan kondisi kesehatan secara perla han dan pasti. Dalam hal ini perhatian ekstra perlu diberikan, mengingat tekanan darah sebenarnya tidak sulit untuk dikendalikan (Kakamu dkk, 2019; Lionakis dkk, 2012).

Mayoritas peserta menunjukkan antusiasme dan perhatian yang tinggi sela ma program, antara la in yang ditunjukkan melalui kehadiran dan kesediaan mengikuti pengobatan komplementer berupapijat, a kupunktur dan herbal yang dianjurkan. Mereka memahami dengan baik manfaat tindakan komplementer, dan menyadari perlunya perbaikan pola hidup. Namun, melalui program ini pun diketahui bahwa merubah pola hidup ternyata memerlukan waktu lebih lama. Kesadaran peserta akan pentingnya kesehatan belum mampu merubah pola hidup yang tidak sehat, sehingga manusia lanjut usia makin menjadi beban keluarga, masyarakat dan negara. Sikap kekeluargaan dan ketulusan dalam penyelenggaraan konsultasi sela ma berlangsungnya program telah berhasil menciptakan keakraban dan kepercayaan dengan peserta. Kondisi ini diperlukan untuk memperoleh kepercayaan dari peserta.

Tabel 7. Kondisi Penyebab Perubahan Profil yang Mencolok pada Beberapa Peserta setelah Perlakuan.

\begin{tabular}{|c|c|c|}
\hline $\begin{array}{l}\text { No } \\
\text { Pasien }\end{array}$ & Perubahan & Keterangan \\
\hline 1 & Terjadi penurunan drastis ka dar gula darah dan kolesterol & $\begin{array}{l}\text { Mengurangi konsumsi telur } \\
\text { menjadi tidak setiap hari } \\
\text { Minum rebusan brotowali }\end{array}$ \\
\hline 2 & $\begin{array}{l}\text { Mencoba mengurangi gorengan, jeroan sehingga kadar kolesterol } \\
\text { menurun drastis }\end{array}$ & Konsumsiba wang putih \\
\hline 4 & $\begin{array}{l}\text { Mencoba menguran gi gorengan dan konsumsi gula. } \\
\text { Kadar gula darah menurun drastis }\end{array}$ & $\begin{array}{l}\text { Konsumsidaun salam, jinten } \\
\text { hitam }\end{array}$ \\
\hline 5 & $\begin{array}{l}\text { Konsumsiputih telur masih setiap hari sehingga kadar koleserol } \\
\text { naik dra stis }\end{array}$ & $\begin{array}{l}\text { Rebusan daun salam tidak berefek } \\
\text { Olahra ga tidak maksimal }\end{array}$ \\
\hline 6 & $\begin{array}{l}\text { Mencoba mengurangi gorengan namun kadar kolesterol malahan } \\
\text { meningkat }\end{array}$ & $\begin{array}{l}\text { Bawang putih dandaun salam } \\
\text { tidak berefek } \\
\text { Olahraga tidak dilakukan }\end{array}$ \\
\hline 7 & $\begin{array}{l}\text { Mencoba menguran gi bakso, empal, soto, daging, udang, . Ka dar } \\
\text { kolesterol naik }\end{array}$ & Da un salamtidak berefek \\
\hline 8 & Mencoba menghentikan konsumsi gu la, garam. Gula darahnaik & $\begin{array}{l}\text { Hanya jintan hitam tidak berefek, } \\
\text { Olahraga tidak dilakukan }\end{array}$ \\
\hline 9 & Mencoba mengendalikan konsumsi gula. Gula darah naik drastis & Pola hidup sulit dikendalikan \\
\hline 10 & $\begin{array}{l}\text { Minum obat antikolesterol, tapi ka dar kolesterol naik.Konsumsi } \\
\text { gorengan, telur a sin, udang tidak terkendali }\end{array}$ & $\begin{array}{l}\text { Rebusan daun salam, jintan hitam } \\
\text { belum berhasil }\end{array}$ \\
\hline 11 & $\begin{array}{l}\text { Mencoba secara keras mengendalikan pola makan sehingga kadar } \\
\text { kolesterol turun drastis }\end{array}$ & Bawang putih,jintan hitam. \\
\hline
\end{tabular}




\begin{tabular}{|l|l|l|}
\hline 12 & $\begin{array}{l}\text { Mencoba pengendalian pola makan, termasuk gorengan. Kadar } \\
\text { kolesterol tinggi sekali }\end{array}$ & $\begin{array}{l}\text { Ba wang putih, kunyit tidak } \\
\text { berhasil, }\end{array}$ \\
\hline 15 & Mencoba mengurangikuning telur, bakso, udang, cumi, soto & $\begin{array}{l}\text { Hanya jamu kunyit asam tidak } \\
\text { membantu }\end{array}$ \\
\hline 16 & $\begin{array}{l}\text { Konsumsimakanan gorengan tidak terkendali sehingga kadar } \\
\text { koesterol naik drastis }\end{array}$ & Ba wang putih tidak berhasil \\
\hline 20 & $\begin{array}{l}\text { Kolesterolnaik drastis. Penjual nasi sehingga konsumsi sulit } \\
\text { dikendalikan . Beratbadan berlebih }\end{array}$ & $\begin{array}{l}\text { Kunyit a sam dan jintanhitam tidak } \\
\text { membantu }\end{array}$ \\
\hline 21 & Kurangi gorengan, kadar kolesterolmenurun drastis & Ba wang putih tidak berhasil \\
\hline 22 & Mencoba mengatur pola makan & Profil darah stabil \\
\hline 23 & $\begin{array}{l}\text { Mengatur pula makan, kadar gula menurun drastis, a sam urat } \\
\text { turun tapi kadar kolesterol naik drastis }\end{array}$ & $\begin{array}{l}\text { Daun salam, jintan hitam tidak } \\
\text { membantu }\end{array}$ \\
\hline 24 & Kolesterolnaik drastis karena pola makan & $\begin{array}{l}\text { Pare, ba wang putih tidak } \\
\text { membantu }\end{array}$ \\
\hline 25 & Gula darah turun, tetapika dar kolesterol masih tinggi & $\begin{array}{l}\text { Daun salam, jintan hitam, tidak } \\
\text { membantu }\end{array}$ \\
\hline 26 & $\begin{array}{l}\text { Gula darah menurun drastis. Tapi kolesterol naik drastis. Kura } \\
\text { karbohidrat }\end{array}$ & Jintan hitam tidak membantu \\
\hline 28 & Kolesterolnaik drastis, gula darah turun drastis & \\
\hline
\end{tabular}

\section{KESIMPULAN}

Pelayanan konvensional dan komplementer secara terpadu pada warga binaan lanjut usia di Wilayah Karang Gayam Teratai, Surabaya, selama sebulan menunjukkan peningkatan pemahaman peserta terhadap kedua sistem pelayanan tersebut untuk memperoleh keadaan sehat. Ketidakmampuan peserta dalam merubah pola hidup selama program menyebabkan ketidakberhasilan peningkatan keadaan kesehatan yang ditunjukkan melalui profil tekanan darah, kadar gula, asa $m$ urat dan kolesterol da lam darah yang melewati batas yang diperkenankan.

\section{SARAN}

Melakukan kegiatan terjadwal sekali sebulan dalam bentuk konsultasi kesehatan berupa penyuluhan, konsultasi pribadi, pemberian obat herbal, a kupunktur dan pijat. Cara ini diharapkan dapat meningkatkan kesadaran peserta untuk menerapkan pola hidup sehat, da pat memenuhi kebutuhan peserta akan perhatian dari tena ga kesehatan terhadap masalah kesehatan dan cara penanganan secara berkelanjutan

\section{UCAPAN TERIMAKASIH}

Terimakasih disampaikan kepada 1) Direktorat Jenderal Pengabdian Masyarakat Kementerian Ristek dan Dikti Republik Indonesia, 2) Pimpinan dan seluruh staf Lembaga Penelitian dan Pengabdian masyarakat Universita s Airlangga.

\section{Daftar Pustaka}

Ahmad, A., Husain, A., Mujeeb, M., Khan, S. A., Najmi, A. K., Siddique, N. A., . . Anwar, F. (2013). A review on therapeutic potential of Nigella sativa: A miracle herb. Asian Pacific Journal of Tropical Biomedicine, 3(5), 337-352. Retrieved https://pubmed.ncbi.nlm.nih.gov/23646296

Andriani A, Chaidir R.(2018). Pengaruh pemberian air rebusan daun salam (Syzygium polyanthum) terhadap penurunan kadar asam urat. Research of
Applied Science and Education. 19;V10.i2 :112119.

https://www.ncbi.nlm.nih.gov/pmc/articles/PMC36424 42/. doi:10.1016/S2221-1691(13)60075-1

Badan POM RI. 2005. Peraturan No :HK.00.05.4.1380.Pedoman Cara Pembuatan Obat Tradisional yang Baik Jakarta : BPOM.

Beers, S. J. (2012). Jamu: The Ancient Indonesian Art of Herbal Healing: Tuttle Publishing.

Dang, D. K., Pucino, F., \& Calis, K. A. (2002). Complementary Therapies for Pharmacists By Steven B. Kayne (Faculty of Homeopathy, London). Pharmaceutical Press, London, UK. 2002. xvii +425 pp. $15.5 \times 23.5 \mathrm{~cm} . £ 28.95$ (\$41.26), paperback. ISBN 0-85369-430-3. Journal of Natural Products, 65(7), 1088-1088. Retrieved

from https://doi.org/10.1021/np020720e. doi: 10.1021/np020720e

Garch Reed, Michael. 1990. Accupresure's Potent Points, United States of America: Bantam Book.

Joseph, B., \& Jini, D. (2013). Antidiabetic effects of Momordica charantia (bitter melon) and its medicinal potency. Asian Pacific Journal of Tropical Disease, 3(2), 93-102. Retrieved from https://www.ncbi.nlm.nih.gov/pmc/articles/PM C4027280/. doi: 10.1016/S2222-1808(13)600523

Kakamu, T., Hidaka, T., Kumagai, T., Masuishi, Y., Ka suga, H., Endo, S., . . Fukushima, T. (2019). Unhealthy changes in eating habits cause acute onset hypertension in the normotensive community-dwelling elderly-3 years cohort study. Medicine (Baltimore), 98(15), e15071. doi:10.1097/md.0000000000015071

Labban, L. (2014). Medicinal and pharmacological properties of Turmeric (Curcuma longa): A review. Int J Pharm Biomed Sci., 5, 17-23.

Lionakis, N., Mendrinos, D., Sanidas, E., Fa vatas, G., \& Georgopoulou, M. (2012). Hypertension in the 
elderly. World journal of cardiology, 4(5), 135-147. Retrieved from https://pubmed.ncbi.nlm.nih.gov/22655162 https://www.ncbi.nlm.nih.gov/pmc/articles/P MC3364500/.doi:10.4330/wjc.v4.i5.135

Ried, K., Toben, C., \& Fakler, P. (2013). Effect of garlic on serum lipids: an updated meta-analysis. Nutr Rev, 71(5), 282-299. doi:10.1111/nure. 12012

Sethi, G., Sung, B., \& Aggarwal, B. B. (2009). The Role of Curcumin in Modern Medicine. In K. G. Ramawat(Ed.), Herbal Drugs: Ethnomedicine to Modern Medicine (pp. 97-113). Berlin, Heidelberg: Springer Berlin Heidelberg.

Thomas, A., Rajesh, E. K., \& Kumar, D. S. (2016). The Significance of Tinospora crispa in Treatment of Diabetes Mellitus. Phytother Res, 30(3), 357-366. doi:10.1002/ptr.5559

\section{DOKUMENTASI KEGIATAN}

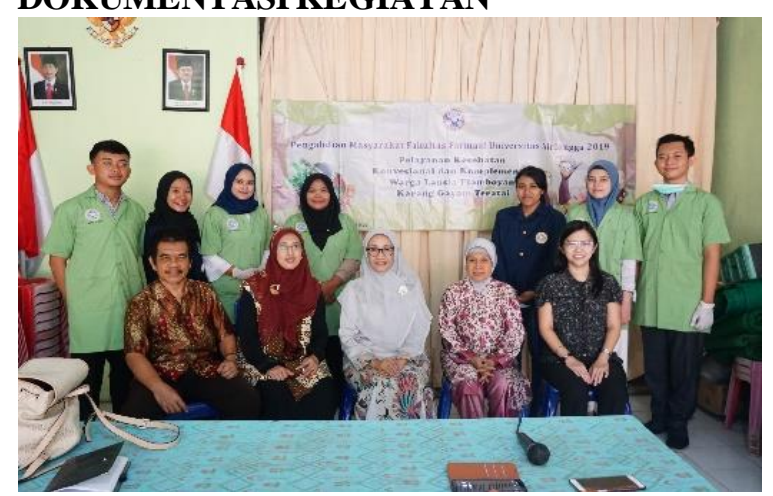

Dosen da n mahasiswa pelaksana Program Pengabdian Ma syarakat Fakultas Farmasi Universitas Airlangga 2019 Karanggayam Teratai, Surabaya (Foto: dokumentasi pribadi).

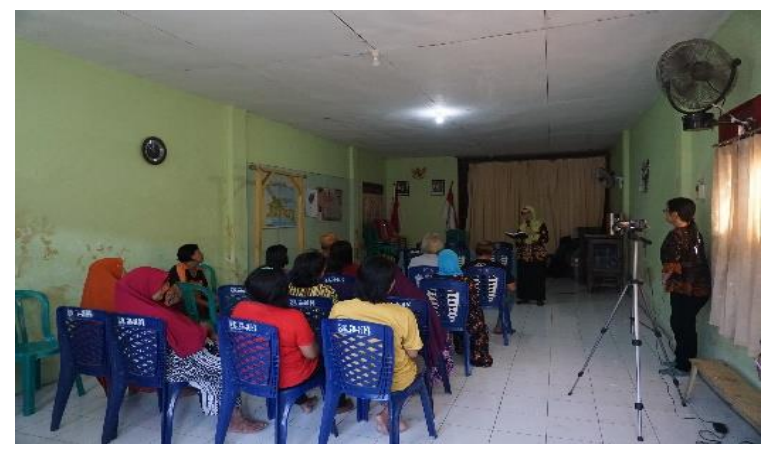

Penyuluhan herbal oleh Prof. Dr. Mangestuti Agil, MS., Apt. (Foto: dokumentasipribadi).
Tjakraningrat, H. (2001). Kitab Primbon Betaljemur Adammakna. Yogyakarta: Soemodidjojo Mahadewa.

Widyawati, T., Yusoff, N. A., Asmawi, M. Z., \& Ahmad, M. (2015). Antihyperglycemic Effect of Methanol Extract of Syzygium polyanthum (Wight.) Leaf in Streptozotocin-Induced Diabetic Rats. Nutrients, 7(9), 7764-7780. doi: $10.3390 /$ nu7095365

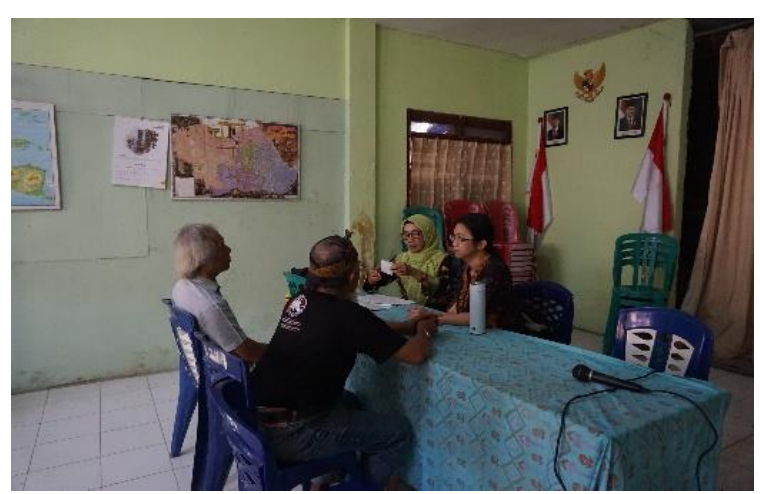

Konsultasi kesehatan oleh tim penyuluh (Foto: dokumentasi priba di). 